\title{
China's Building of Overseas Military Bases: Rationale and Challenges
}

\author{
Xue Guifang and \\ Zheng Jie
}

\begin{abstract}
China's military capability to perform out-of-area operations and provide international public goods falls short of the increasing need to protect its expanding economic, political, and security interests abroad. Overseas military bases can not only facilitate the soft application of China's growing hard power, but also benefit the host nations in terms of national security, economic development, and job creation. A strong case can be made on both legal and precedential grounds for China's construction of overseas military bases in the future. It is irreproachable for a great power like China to have overseas military installations as long as the Charter of the United Nations, host nations' laws, and the longstanding non-intervention policy are upheld. Planning for overseas base-building
\end{abstract}

Xue Guifang is Professor of Ko Guan Law School, Shanghai Jiao Tong University. She can be reached at juliaxue@sjtu.edu.cn. Dr. Zheng Jie is Assistant Research Fellow at the School of Naval Architecture, Ocean \& Civil Engineering, Shanghai Jiao Tong University.

(c) 2019 World Century Publishing Corporation and Shanghai Institutes for International Studies China Quarterly of International Strategic Studies, Vol. 5, No. 4, 493-510

DOI: 10.1142/S237774001950026X

This is an Open Access article, copyright owned by the SIIS and WCPC. The article is distributed under the terms of the Creative Commons Attribution-NonCommercial 4.0 (CC BY-NC) License which permits use, distribution and reproduction in any medium, provided that the original work is properly cited and is used for non-commercial purposes. 
must involve shaping an international environment that accepts Chinese military presence and conducting systemic risk assessments and practical solutions on such related matters as the location, size, functions, law enforcement, and maintenance of each military base.

Keywords: Military base; China; overseas interests; legal environment.

As China's economic engagement with the rest of the world continues to increase, there is a growing need for its military to undertake overseas nonwar missions (such as disaster relief and anti-piracy) to protect its expanding commercial, political, and security interests on the one hand, and provide more global public goods on the other. However, a number of challenges have to be overcome before the Chinese military can perform these out-of-area operations, chief among which is the absence of military bases abroad that can serve as staging points.

The use of force has been strictly restricted under current international political, economic, and legal circumstances. As a result, overseas military bases are increasingly utilized to serve peaceful purposes. Given multiple precedents and a permissive international legal framework, China's plan to build military installations abroad can be justified. Yet, amid intensifying strategic competition between Beijing and Washington, any talk of China's building of military bases abroad is likely to be met with growing suspicion or outright opposition from the West. At the same time, due to the complicated nature and political sensitivity of military base construction, Chinese overseas military presence could be subject to heightened security and legal scrutiny in prospective host nations. Facing these difficulties, Chinese military-base planning must involve not only strenuous efforts to create a more favorable international environment, but also comprehensive risk assessments and practical solutions to address key issues surrounding military base construction, such as related diplomatic negotiations, law enforcement, as well as daily operation and maintenance of the military bases.

\section{China's Overseas Military Bases: Legitimacy and Legality}

In today's world, overseas military installations are increasingly used as staging points for non-combat missions. As a growing economic power, it 
is natural and necessary for China to develop a limited number of overseas military bases to protect its international trade and overseas investment. Such an effort is also in line with international laws and state practices.

\section{Expanding Interests and a Force for Peace}

As China's economy and global influence continue to grow, there is an increasingly urgent call for China to shoulder more international responsibilities for prosperity and peace in the world. Meanwhile, China has come to realize that more international responsibilities imply growing global presence not only in the form of greater economic integration and diplomatic engagement, but more importantly, military capabilities as an essential instrument for safeguarding world peace and protecting China's expanding array of overseas interests. For a truly great power, ideally, its military should stand behind each step of its increasing responsibilities and expanding interests.

It is estimated that by 2030, China will have become the world's largest creditor nation with an aggregate investment of $\$ 3$ trillion and more than 10 million Chinese nationals employed abroad. China's lasting economic growth depends on safe and sustained access to foreign natural resources and markets. The military force, therefore, is the ultimate safeguard of all these overseas interests. ${ }^{1}$ But the reality is that China's political leverage, economic influence, diplomatic flexibility, and in particular military capabilities, have fallen short of the growing need to protect its interests abroad. China's historical experience and foreign policy tradition have also contributed to Beijing's reservations about displaying military force in a high profile way, let alone projecting its military power far offshore to address security challenges and protect overseas interests. Even if Beijing decides to adjust its long-held nonintervention policy and elevates the military's role in its foreign policy toolkit, the lack of overseas bases as staging points still makes it difficult

${ }^{1}$ Chen Guoquan, “China's Logistical Support Facilities in Djibouti: Things to Know [中国在吉布提保障设施建设, 这些值得了解], " Ministry of Defense of the People's Republic of China, December 4, 2016, http://www.mod.gov.cn/jmsd/2016-12/04/content_4765618_2.htm. 
for the Chinese military to play a prominent role in overseas interest protection. $^{2}$

For example, when a Chinese cargo ship was taken hostage by Somalian pirates in the Indian Ocean in October 2009, Beijing had to resort to the headquarters of the EU NAVFOR Atalanta Operation via the International Maritime Organization to coordinate a rescue operation, because even the nearest Chinese naval escort fleet in the region could not perform a timely and effective operation. The incident underscores the fact that with-

China needs to begin building overseas military bases to protect its expanding overseas interests and better fulfill international responsibilities. out overseas military bases or regular contingency security forces, China's navy however strong it is - can only play a passive role at best in times of emergency. As another example, 75 Chinese enterprises suffered a total loss of nearly $\$ 20$ billion in the Libyan civil war in $2011 .^{3}$ Had the Chinese frigate Xuzhou not happened to be on an escort mission in the Gulf of Aden and the Chinese government not mobilized enough diplomatic, political, and commercial resources complete with foreign governments' logistical support, the more than 30,000 Chinese nationals working and living there would not have been able to be evacuated within a week. Evidently, without full-fledged overseas bases, Chinese military capabilities will be constrained when it comes to power projection, logistical support, and strategic warning. For the Chinese military to play a more active and prominent role in protecting vital national interests and serve as a force for world peace, it is imperative for China to begin building overseas military bases.

It is worth noting that the Chinese facilities in the Djibouti port are not a military base, because they have not lived up to military standards in

${ }^{2}$ Song Yunxia and Wang Quanda, The Legal Guarantees for Military Protection of Overseas Interests (Beijing: China Ocean Press, 2014), p. 23.

3“Chinese Companies' Economic Loss Revealed in Libya Crisis [利比亚动荡一中国企业损失浮出水面]," Beijing Youth Daily, March 25, 2011, http://news. sohu.com/20110325/n279988001.shtml. 
terms of size and functions, such as housing naval vessels. ${ }^{4}$ Commercial ports on foreign soil, no matter how well-developed, are not reliable and effective staging points for China's military operations. Although commercial ports in friendly countries can also "increase the range, flexibility, and sustainability of Chinese maritime endeavors, ${ }^{5}$ they are more expensive to maintain and more vulnerable in times of political uncertainty, and cannot house large naval vessels or store ammunition. Base facilities in commercial ports are unlikely to serve as a viable logistical alternative if the intensity of Chinese military out-of-area operations increases in parallel with China's expanding global economic, political, and security interests. ${ }^{6}$ After all, the operation of facilities for commercial purposes on a foreign port has always revolved around business interests and cannot place other functions ahead of economic considerations. ${ }^{7}$ With more out-of-area operations to be performed and growing support by the Chinese public, the navy of the People's Liberation Army (PLAN) cannot rely indefinitely on commercial facilities alone to support its overseas operations. ${ }^{8}$

\section{International Law, Bilateral Arrangements, and Domestic Legislation}

International law and precedents further bolster the case for China's building of overseas military bases.

First, relevant articles of the Charter of the United Nations and basic principles of international law grant states legality to station troops abroad. As military force is increasingly seen as playing a prominent role in addressing non-traditional security challenges, its status in international

\footnotetext{
${ }^{4}$ Chen Guoquan, “China Builds Logistical Support Facilities in Djibouti, Things Worth Noting [中国在吉布提保障设施建设, 这些值得了解], " Chinese Defense Ministry, December 4, 2016, http://www.mod.gov.cn/jmsd/2016-12/04/content_4765618_2.htm.

${ }^{5}$ Rajeev Ranjan Chaturvedy, “China's Strategic Access to Gwadar Port: Pivotal Position in Belt and Road," RSIS Commentary, January 6, 2017, https://www.rsis.edu.sg/wp-content/ uploads/2017/01/CO17005.pdf.

${ }^{6}$ Christopher D. Yung, et al., Not an Idea We Have to Shun: Chinese Overseas Basing Requirements in the 21st Century (Washington, D.C.: National Defense University Press, 2014), p. 25.
}

${ }^{7}$ Ibid., p. 24.

${ }^{8}$ Christopher D. Yung, et al., Not an Idea We Have to Shun: Chinese Overseas Basing Requirements in the 21st Century, pp. 12-14. 
law has been promoted accordingly. Since overseas military bases play the dual role of protecting national and international security, the Charter of the United Nations recognizes the special legal status of overseas bases. ${ }^{9}$ To be more specific, UN members "undertake to make available to the Security Council...armed forces, assistance, and facilities, including rights of passage, necessary for the purpose of maintaining international peace and security," which effectively acknowledges the legality as well as legitimacy of overseas bases. ${ }^{10}$ Member states' inherent right of individual or collective self-defense is also enshrined in the Charter, which means the right may be exercised through a foreign military base. Under the UN auspices, a military base may be set up in a member state for the purpose of maintaining international collective security. ${ }^{11}$ Moreover, a strategic area may be designated on the trust territory under an international trusteeship agreement. ${ }^{12}$ All the above provisions indicate that the role of military bases in the maintenance of international peace cannot be discounted, and that their legal status is recognized by international law.

Second, some countries' domestic laws allow foreign military bases on their soil and some even welcome the presence of foreign troops. The role of military bases is legalized through specific arrangements, such as bilateral treaties or agreements. ${ }^{13}$ In practice, a fair number of countries (for example, South Korea, Japan, Belgium, Turkey, the Philippines, and some Middle Eastern countries) host foreign troops in exchange for economic or security benefits

The legal status of overseas military bases is recognized by international law.

${ }^{9} \mathrm{Li}$ Bojun, “On the International Legal Status of Overseas Military Base [论海外军事基地的国际法律地位问题], Journal of Hunan University of Science and Technology, No. 4 (2016), pp. 63-68.

${ }^{10}$ Article 43 of the UN Charter, https://www.un.org/en/sections/un-charter/un-charterfull-text/.

${ }^{11}$ Article 51 of the UN Charter, https://www.un.org/en/sections/un-charter/un-charterfull-text/.

${ }^{12}$ Article 82 of the UN Charter, https://www.un.org/en/sections/un-charter/un-charterfull-text/.

${ }^{13}$ Sun Degang, "An Analysis of the Conditions for Major Powers' Deployment of Overseas Military Bases [大国海外军事基地部署的条件分析]," World Economics and Politics, No. 7 (2015), pp. 40-67. 
in the form of high rents, military technical assistance, and preferential trade terms, among other things. For example, the high rents paid by Russia for its military bases in Tajikistan have become an important source of government revenue for Dushanbe. Some host nations like Turkey welcome foreign military presence as a means of reducing its own defense spending and increasing regime security. ${ }^{14}$

Host nations may also want to house foreign bases because the operation and maintenance of these bases may generate job opportunities for local residents. Some countries either lay out the conditions, status, and purposes of housing foreign military presence in their constitutions, or make specific laws detailing the ways in which foreign troops are maintained and managed. For example, Article 185 of the Constitution of Belgium states that "Foreign troops may only be admitted to the service of the State, or occupy or cross the territory by virtue of a law." ${ }^{15}$ Article 60 of South Korea's Constitution also gives its National Assembly "the right to consent to the declaration of war, the dispatch of armed forces to foreign states, or the stationing of alien forces in the territory of the Republic of Korea." ${ }^{16}$ Other domestic legislation, such as Turkey's Constitution, Britain's Visiting Forces (Military Courts-Martial) Order of 1942, the United States' Military Extraterritorial Jurisdiction Act of 2000, and Latvia's Status of Foreign Forces, all prescribe the acceptable behavior on the part of foreign troops as a way of limiting the negative effect of foreign military presence on ordinary citizens' life on the one hand, and addressing the host nations' security concerns on the other.

Apart from domestic legislation, in practice, the role, purposes, and legal status of foreign troops are more often established through bilateral agreements that reflect the two parties' common interests and shared values. Examples of these bilateral arrangements are many, including the UK-U.S. agreement lasting from 1946 to 2014 that allowed the U.S. troops' presence in Great Britain for mutual defense; and the two U.S.-Philippine arrangements valid from 1956 to 1992 and 2001 to 2014, respectively, in

${ }^{14}$ Ibid.

${ }^{15}$ Belgian House of Representatives, The Belgian Constitution, Article 185, October 2007, p. 56.

${ }^{16}$ South Korean National Assembly, The Constitution of the Republic of Korea, Article 60, p. 18. 
which Manila agreed to host American troops to address its economic, defense, and security concerns. ${ }^{17}$ The United States, as of September 2014, had deployed nearly 600 military bases and installations around the world through bilateral agreements with more than 100 countries. $^{18}$ In the meantime, countries which plan to deploy military bases on foreign soil must act as responsible powers ready to consolidate the legality of the prospective military bases through bilateral arrangements while providing an increasing share of global public goods in accordance with international law. ${ }^{19}$

Third, Chinese domestic legislation and international precedents have also laid the ground for building overseas bases. Since China does not have overseas military bases for now, some countries, citing China's long-held non-intervention policy, oppose China's attempt to build any military bases on foreign soil. ${ }^{20}$ However, in both legal and political terms, the principle of non-intervention is derived from sovereign equality, the cardinal principle that governs modern state-to-state relations. ${ }^{21}$ A closer reading of China's domestic legislation proves that future deployment of overseas military bases does not undercut the principles of sovereign equality and non-intervention, and that overseas base-building is in line with Beijing's commitment to the Five Principles of Peaceful Coexistence and the role it plays as a responsible stakeholder. ${ }^{22}$

${ }^{17}$ Stacie L. Pettyjohn and Jennifer Kavanagh, "Access Granted:Political Challenges to the U.S. Overseas Military Presence, 1945-2014," RAND Corporation, 2016, https://www. rand.org/pubs/research_reports/RR1339.html.

${ }^{18}$ Department of Defense, The Base Structure Report (BSR) - FY 2015 Baseline: A summary of the Real Property Inventory (Washington, D. C.: Department of Defense, 2014), http://www.acq.osd.mil/eie/Downloads/BSI/Base\%20Structure\%20Report\%20FY15.pdf.

${ }^{19}$ Sun, "An Analysis of the Conditions for Major Powers' Deployment of Overseas Military Bases," p. 65.

${ }^{20}$ Three white papers released in the 1990s, namely, China's Arms Control and Disarmament (1995) and China's National Defense (1998 and 2000 editions), all declare that China will not station troops or build military bases abroad. These documents and its long-held non-intervention policy are often cited by some countries in opposition to China's attempt to build overseas military bases.

${ }^{21}$ Chen Feng, "A Method to Prove Nonintervention as a Principle of Customary International Law [不干涉原则作为习惯国际法之证明方法]," Jurist, No. 5 (2012), p. 163.

${ }^{22}$ Song and Wang, The Legal Guarantees for Military Protection of Overseas Interests, p. 112. 
China's National Defense Law grants the state the power, in commensurate with the needs for national development, to adopt defensive measures, build support facilities, and develop an appropriate size of armed forces, for the purpose of protecting national security. The Law also emphasizes that any international military exchange and cooperation must be conducted on the basis of the Five Principles of Peaceful Coexistence, and that China endorses the international community's military activities for peaceful purposes and abides by the treaties and agreements it has signed with other states or which it accedes to. ${ }^{23}$ In a word, China's overseas military base arrangements will be made according to its development interests and the principle of non-intervention, in accordance with international law, and for the purpose of international peace and common development.

Both China's

domestic law and

international

precedents allow for

China's overseas

military

base-building.

By China's National Security Law, Chinese national security is guaranteed by military security and underpinned by international security. In the face of both traditional and non-traditional security challenges, China will actively conduct international security cooperation and fulfill international obligations. Moreover, China adopts a military strategy of a defensive nature, develops armed forces of a size commensurate with its national interests, and takes defensive measures deemed necessary to protect its national sovereignty and overseas interests. The Law not only articulates the peaceful purpose and principal missions of China's armed forces, but also gives power to the state to employ all necessary measures for national defense, not ruling out the possibility of military installations abroad to protect national interests and provide public goods for international security. $^{24}$

In terms of international military diplomacy, China has signed an agreement on joint military exercises with other members of the Shanghai

${ }^{23}$ See Articles 8, 23, 26, 28, 65, 66, and 67 of the Law of the People's Republic of China on National Defence.

${ }^{24}$ National People's Congress, National Security Law of the the People's Republic of China [中华人民共和国国家安全法]，July 1，2015，http://www.gov.cn/xinwen/2015-07/01/content_2888316.htm. 
Cooperation Organization (SCO) and another agreement with Russia regarding the status of troops on each other's territories during joint military exercises. The two documents prescribe the status and behavior of Chinese troops on foreign soil. For example, China has made the commitment to respect the host nation's sovereignty, laws, traditions and customs, refrain from interfering in their internal affairs or engaging in any political activity, do nothing that might in any way damage or harm the host nation's natural resources, environment, or cultural relics. Both documents could serve as a basis for future legal frameworks that govern how Chinese troops and military bases on foreign territories are managed and maintained - either bilaterally or multilaterally. ${ }^{25}$

Beijing has also adapted its non-intervention policy to the evolving geopolitical and geo-economic landscapes of the world. After the initial muted reaction to the Middle East political upheavals originating in Tunisia in 2010, Beijing began to participate in regional political and security matters as a third party by making a number of proposals regarding the civil wars in Libya and Syria as well as the peaceful settlement of Israeli-Palestinian conflicts. ${ }^{26}$ In recent years, China has been trying to present itself as a constructive actor in the Middle East, sometimes mediating among conflicting parties and at other times helping convene multilateral meetings among regional stakeholders. These exercises in constructive intervention are welcomed by regional countries and the international community at large. ${ }^{27}$

${ }^{25}$ National People's Congress, SCO Member States' Agreement on the Joint Military Exercise [ 上海合作组织成员国关于举行联合军事演习的协定], June 2007, http://www.npc.gov. cn/wxzl/gongbao/2009-02/05/content_1505224.htm; and National People's Congress, Treaty on the Temporary Stay of the Army of One Party in the Territory of the Other Party during the Period of Joint Military Exercises between the People's Republic of China and the Russian Federation [部队临时处于对方领土的地位的协定], June 2007, http://www.npc.gov.cn/wxzl/wxzl/200706/29/content_1461976.htm.

${ }^{26}$ Zhou Shixin, “China's Constructive Intervention in Middle East Upheavals [中国对中东变局的建设性介入]," Arab World Studies, No. 2 (2013), pp. 40-51.

${ }^{27}$ Zhao Huasheng, “Nonintervention in Internal Politics and Constructive Intervention - Afterthought on China's Response to Kyrgyzstan's Upheaval [不干涉内政与建设性介入一一吉尔吉斯斯坦动荡后对中国政策的思考], J Journal of Xinjiang Normal University, No. 1 (2011), pp. 23-27; and Chen Dongxiao, “China's Foreign Policy Transformation in the 2010s [新世纪前十年中国外交布局的转型和升级], Global Review, No. 6 (2012), pp. 1-13. 
China's policy position on UN peacekeeping has also been fundamentally changed. Initially opposing peacekeeping operations under the UN auspices as a form of violation of national sovereignty, Beijing has now become one of the leading contributors of troops and funding to UN peacekeeping missions since April 1992, when China first dispatched 400 PLA soldiers on a UN peacekeeping operation to Cambodia. Instead of undercutting the official non-intervention policy, Beijing's participation in UN peacekeeping operations demonstrates its diplomatic flexibility and open-mindedness toward sending troops abroad for international security purposes.

\section{Potential Contributions of China's Overseas Military Presence}

Overseas military bases have high strategic value because they are staging points for armed forces' combat, defense, and training operations. From a traditional geopolitical perspective, the path toward a real great power with the capability to exert a meaningful strategic impact and protect its overseas interests around the world - always starts with building military bases abroad. ${ }^{28}$ All maritime powers in history adopted a high-risk and rich-reward base-building strategy that enhanced their maritime dominance through global control of key points of waterways. ${ }^{29}$

Overseas military base-building is a necessary step for China to grow into becoming a real global power.

History also suggests that a strategy of "going global" militarily would achieve little without firm control of island bases and vital straits. ${ }^{30}$ For instance, India had been an economically seclusive country until the 1980s. Since the beginning of the 1990s, along with economic openness and democratic reform, India's military modernization has been accepted and sometimes welcomed. As a result, New Delhi has been trying to project

${ }^{28}$ Sun, "An Analysis of the Conditions for Major Powers' Deployment of Overseas Military Bases."

${ }^{29}$ Liang Fang, Studies on Key Strategic Waterways (Beijing: Current Affairs Press, 2011), p. 141.

${ }^{30} \mathrm{Hu}$ Bo, China's Sea Power Strategy: Diplomacy, Blue Economy, and Naval Power (Beijing: Xinhua Publishing, 2012), p. 32. 
its power and deterrent capabilities in the Indian Ocean to strengthen its freedom of action and better protect its expanding interests abroad. ${ }^{31}$ Defense partnerships and institutionalized military exchanges have been set up between New Delhi and Southeast Asian nations, increasing India's naval soft power and strengthening its role in shaping a secure maritime environment. Coastal surveillance radar stations have been built in the Maldives, Mauritius, and Madagascar through India's extensive military cooperation with nearby nations. ${ }^{32}$ At present, India is building a naval base in Seychelles after the two countries reached an agreement in 2015. ${ }^{33}$ Surveillance stations and a future naval base will enable New Delhi to acquire a number of strategic footholds in the Indian Ocean. ${ }^{34}$

The legal status of overseas bases in international law is also evolving. ${ }^{35}$ In today's world, military force is increasingly used to address nontraditional security challenges like terrorism, piracy, and natural disasters; international rules and norms, as well as global public opinion, all impose strict constraints on the use of force. Military bases that were used principally for war fighting in the past are now deployed mainly to serve other purposes, such as public diplomacy, information collection, expatriate protection, social governance, and scientific research. ${ }^{36}$ More nations now welcome the presence of military bases and foreign troops as they play an

${ }^{31}$ Ajaya Kumar Das, “Soft and Hard Power in India's Strategy toward Southeast Asia," India Review, Vol. 12, No. 3 (2013), pp. 165-185.

32“List of Countries with Overseas Military Bases," https://en.wikipedia.org/wiki/ List_of_countries_with_overseas_military_bases.

33 "India to Form Its First Naval Base in Seychelles to Tighten Vigil over Indian Ocean: Read to Know More," December 28, 2015, http://indiatoday.intoday.in/education/story/ naval-base-in-seychelles/1/557245.html; and Rezaul H. Laskar, "India, Seychelles Agree to Work on Assumption Island Naval Base Project," Hindustan Times, June 25, 2018, https:// www.hindustantimes.com/india-news/india-seychelles-agree-to-work-on-assumption-island-project-respect-concerns/story-0nlhY13WxOgbJDTdGZIjaL.html.

${ }^{34} \mathrm{Li}$ Jiasheng, “An Effectiveness Assessment of India's Maritime Strategy [印度海洋战略成效评估]," Pacific Journal, No. 4 (2016), pp. 62-72.

${ }^{35}$ Sheng Hongsheng, "International Criminal Law and Reconstruction of Post-Cold War International Legal Order [国际刑法与冷战后国际法律秩序的重构], "Legal Forum, No. 1 (2015), pp. 31-36.

${ }^{36}$ Sun, "An Analysis of the Conditions for Major Powers' Deployment of Overseas Military Bases." 
increasingly prominent role in protecting sea lanes, supporting UN peacekeeping operations, and providing humanitarian assistance.

For example, after a tsunami hit Indonesia in late December 2004, troops from many countries were involved in multinational humanitarian assistance operations. A U.S. carrier battle group stood at the frontline of the multilateral mission and the U.S. military forces were highly commended for humanitarianism and generosity. Such exercises in naval soft power were also seen in Britain's utilization of miniaturized military bases abroad to crack down on Somali pirates, evacuate expats, and contain antiWestern regimes. ${ }^{37}$ French troops stationed in some parts of Africa also intervened in some African civil wars in the name of humanitarian assistance as a way both to protect French interests and provide relief to local residents and foreigners in times of crisis.

\section{China's overseas} military bases will mainly serve peaceful purposes.

Notably, the PLA's first overseas base will be very different from traditional Western military bases. Beijing will refrain from interfering in internal affairs of prospective host countries; instead, it will operate with the endorsement of the United Nations, regional organizations, and governments of the concerned countries. ${ }^{38}$ An examination of the case of China's base facilities in Djibouti indicates the potential contributions that China's future military bases will make to world peace and prosperity. First, as a logistical support facility, it will be mainly used to provide rehabilitation for the Chinese troops taking part in escort missions in the Gulf of Aden and waters off Somalia, UN peacekeeping, and humanitarian assistance. Second, it will bolster China's capabilities to protect China's security interests in Africa and the Middle East, and facilitate closer military and counterterrorism cooperation with African and Arab countries. And third, the Djibouti base could also play a key role in securing China's Belt and Road

${ }^{37}$ Sun Degang, “The Imperial Anchor: Britain's Basing Arrangement and Its Strategic Adaptation [帝国之针:英国海外军事基地的部署及其战略调整]," Military History， No. 4 (2015), pp. 67-75.

${ }^{38}$ Wang Lei, “Djibouti Can Become a New Window of Military Cooperation between China and the United States [吉布提可以成为中美军事合作的新窗口]," World Affairs, No. 16 (2017), pp. 56-57. 
Initiative, especially the Maritime Silk Road, which is helpful for promoting the common economic development of countries along the Belt and Road.

Therefore, as a tool to strengthen its naval soft power, overseas bases will not only expand China's military presence by serving as strategic footholds and staging points for better protecting China's expanding interests abroad, but they can also be used to ensure world peace and stability, as the international community is expecting Beijing to take on more international responsibilities.

\section{Future Challenges and Recommend Responses}

China's late arrival at a strategic port that has long hosted U.S. and allied troops could draw Djibouti into a rivalry between the established superpower and the rising one, which might lead to intensifying frictions between China and other regional powers. There are growing concerns that, given its economic strength, China may increasingly participate in Djibouti's port activities, which will give it an additional leverage over other players.

The United States has been the first to express such concerns in public. Washington has warned that Djibouti's alarming levels of debt to China might force the country to concede control of some of its ports to Beijing, which will heighten the insecurity of U.S. and Western military facilities. ${ }^{39}$ France contends that China is trying to acquire a privileged position in Djibouti to gradually weaken Paris's influence there. ${ }^{40}$ Japan is planning to expand its own base in large part to counter China's growing military presence at the site. ${ }^{41}$ India has also shown its displeasure at China's naval

${ }^{39}$ Idrees Ali and Phil Stewart, "Significant Consequences If China Takes Key Port in Djibouti: U.S. General," Reuters, March 7, 2018, https://af.reuters.com/article/africaTech/ idAFKCN1GJ0RBOZATP?feedType=RSS\&feedName=topNews.

${ }^{40}$ Jean-Pierre Cabestan, “China's Military Base in Djibouti: A Microcosm of China's Growing Competition with the United States and New Bipolarity," Journal of Contemporary China, 2019, p. 14.

${ }^{41}$ Hinichi Fujiwara, "Japan to Expand SDF Base in Djibouti in Part to Counter China," Asahi Shimbun, November 15, 2018, http://www.asahi.com/ajw/articles/AJ201811150063. html. 
base, although it has no base facilities in Djibouti. ${ }^{42}$ Many African countries share the view that the construction of China's Djibouti base contradicts its long-held opposition to - and criticism of - U.S. and other major powers' overseas military bases as symbols of imperialism and hegemonism. ${ }^{43}$

As discussed previously, such opposition to China's efforts to build overseas bases cannot be justified. To counter malicious opposition and ease the legitimate concerns about China's strategic intentions, Beijing may intensify its participation in UN peacekeeping missions and multilateral humanitarian assistance, play a more constructive role in regional hot-spot issues, and provide more global public goods for common security and prosperity. ${ }^{44}$ In the long run, China is very likely to become a reliable partner in the concerted global endeavor to address emerging security risks confronting the international community.

Nonetheless, significant challenges must be handled carefully before Beijing goes all out in military base-building. With the return of great power competition, China faces mounting political and military pressure, growing international suspicion, and intensifying scrutiny generated by a renewed sense of "China threat." China's military base-building plans need to take a number of questions into consideration. First, to what extent will military base-building taint China's image as a peaceful rising power? Second, how will overseas bases enable China to better handle broader military contingencies or protect interests abroad? Third, will military bases on foreign soil undercut Beijing's friendly relations with the host nations or produce irreversible adverse effects on the local environment? Fourth, what can China do to settle disputes with other military powers over military base-building? And fifth, are the economic costs of military base-building affordable in the eyes of the Chinese public? To address these questions, Beijing should focus on the following aspects.

${ }^{42}$ Abhijit Singh, “China's Military Base in Djibouti: Strategic Implications for India," War on the Rocks, August 21, 2017, https://warontherocks.com/2017/08/chinas-militarybase-in-djibouti-strategic-implications-for-india/.

${ }^{43}$ Cabestan, “China's Military Base in Djibouti: A Microcosm of China's Growing Competition with the United States and New Bipolarity," p. 4.

${ }^{44}$ China's Military Strategy White Paper, State Council Information Office, May 26, 2015, scio.gov.cn/zfbps/ndhf/2015/Document/1435159/1435159.htm. 
To begin with, any military base-building arrangement must be hinged on a friendly and reliable bilateral relationship. Upholding the Charter of the United Nations and UN Security Council (UNSC) resolutions, China should engage in political and diplomatic negotiations and consultations with prospective host nations in seeking non-permanent military bases subject to international collective security mechanisms. International security cooperation in geographically important areas should be intensified in pursuit of closer governmental and military ties with potential host nations. In selecting partners, Beijing must carefully evaluate potential host nations' capabilities in meeting China's needs for logistical support, base maintenance, and public goods provision. After a bilateral agreement is reached, Beijing can provide more military assistance to the host nation in such forms as training, education, technical support, as well as military materials. Three pairs of relationship must be handled with great care: relationship with the host nation, relationship with the host nation's neighbors, and relationship with leading military powers. ${ }^{45}$

Besides, the size of overseas bases should be kept at a level commensurate with the requirement of out-of-area missions. In the near future, overseas bases will serve as staging points for China's navy to perform lowintensity and non-combat operations. There is no need to build military bases used for large-scale war fighting, but more resources and funds should be allocated to improve the infrastructure and logistical services in the military facilities. In terms of modes of operation and maintenance, overseas military bases can be either managed by the Chinese side or comanaged with the host nation or entrusted to the host nation, depending on local conditions and the host nation's will and capabilities. At present, a sprawling and all-purpose overseas base is more likely to be an economic burden both on China and the host nation. An ideal overseas military base should focus on performing supply and logistical functions, where the Chinese military forces operate in a restrictive political and legal environment that might not include permission to conduct combat operations. ${ }^{46}$ Compared with the Djibouti base, future overseas bases may have the capacity to store ammunition, repair and replenish naval vessels, and provide

${ }^{45}$ Yung et al., Not an Idea We Have to Shun: Chinese Overseas Basing Requirements in the 21st Century, p. 44.

${ }^{46}$ Ibid., p. 2. 
timely medical services to support anti-terrorism, anti-piracy, and other operations to address non-traditional security challenges.

China must start by focusing on

non-combat

functions in building

overseas military

bases.

Finally, domestic legislation should be advanced to strengthen law enforcement concerning overseas military base-building. Despite the provisions in the national defense and security laws on the role of the Chinese military in defending national interests and conducting military cooperation, more specific regulations should be added to China's Constitution and other domestic laws on protecting overseas interests and peaceful development of military bases abroad, and increasing the legality of Chinese military presence abroad. Case studies of leading military powers' out-of-area military operations, bilateral and multilateral arrangements on foreign troop presence, and domestic legislation on overseas military bases need to be conducted from legal, theoretical, and policy perspectives to offer lessons and precedents for Beijing to make necessary laws on overseas military bases and operations.

\section{Conclusion}

In today's world, overseas military bases are no longer synonymous with hegemony or aggression, but increasingly play a peace-serving role. Adapting to new challenges in the evolving geo-economic and geopolitical landscapes of the present times, Beijing should amend domestic laws on the use of armed forces, more actively conduct international military cooperation, take more international responsibilities to win wider global support, and create a more benign international environment for its effort to build overseas bases. Beijing must make it clear to the world that its military capabilities to protect its expanding overseas interests have fallen short due to lack of full-fledged bases abroad, and that future military bases will only be used to protect its national interests from external threats. Meanwhile, Beijing should step up its engagement in hot-spot issues in such areas as the Middle East, send more troops abroad for peacekeeping operations, conduct robust naval diplomacy, and provide more public goods for 
international security, so as to demonstrate that the Chinese military is a force for world peace.

Most importantly, China should build its overseas military bases in a way that is different from the model of traditional military powers. In terms of foreign policy orientation and economic conditions, China is now ready and able to implement its military base-building programs in an incremental manner. Whether through bilateral or multilateral channels, Chinese overseas bases must be acquired through reciprocal negotiations and consultations on an equal footing. By having a limited size and entrusted with specific missions to perform, China's overseas military bases are expected to bring genuine benefits to the world. 